\title{
THE BRITISH SOCIETY FOR THE HISTORY OF SGIENGE
}

The British Society for the History of Science welcomes members from all backgrounds, in the UK and internationally. Current members include academics, writers, students, museums professionals, schoolteachers and anyone with an interest in some aspect of the history of science, technology and medicine. Details of the annual subscription can be found on our website www.bshs.org.uk, or from the Executive Secretary at the address below.

BJHS Themes is a fully open access journal for the history of science community. It aims to publish scholarly and engaging collections of history of science papers which address provocative themes, and which will be free for readers and offer no financial barrier to publication for authors. Like its sister publication, British Fournal for the History of Science, BJHS Themes is a journal of the British Society for the History of Science, a major learned society for its subject. Issues are available at the following URL: https://www.cambridge.org/core/journals/bjhs-themes

The Society's magazine, Viewpoint, an informal publication, appears three times a year. It is free to members, $£ 12.00$ for institutions and UK non-members, $£_{17.00}$ for overseas non-members from the Executive Secretary.

Administrative business of the Society is handled by Lucy Santos, Executive Secretary, British Society for the History of Science, PO Box 3408, Norwich, NR3 3WE. The Society is registered in England as a Limited Company (No. 562208) and is a Registered Charity (No. 258854). Email office@bshs.org.uk.

Information about the Society is available through the Internet: http://www.bshs.org.uk

Advertising: Contact the Journals Advertising Manager, Cambridge University Press, University Printing House, Shaftesbury Road, Cambridge GB2 8BS.

Information on the BfHS Themes and all other Cambridge journals can be accessed via cambridge.org/core

Cover image: Charles Robert Darwin, as an ape, holds a mirror up to another ape. Colour lithograph by F. Betbeder. Faustin, 1847 - https://wellcomecollection.org/works/ard22k3c 


\section{BJHS}

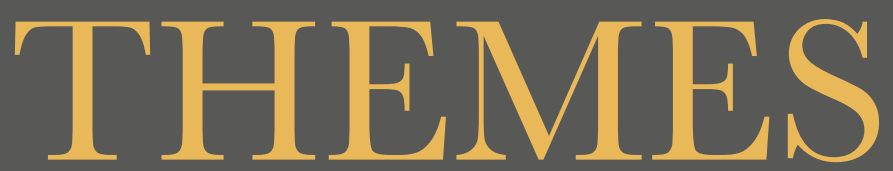

Descent of Darwin: race, sex, and

human nature

\section{Guest edited by Erika Lorraine Milam \& Suman Seth}

\section{VOLUME 62021}

1 Descent of Darwin: race, sex, and human nature ERIKA LORRAINE MILAM AND SUMAN SETH

$9 \quad$ Sexual selection as race making MYRNA PEREZ SHELDON

25 'Constitutions selection': Darwin, race and medicine SUMAN SETH

45 The meaning of absence: the primate tree that did not make it into Darwin's The Descent of Man MARIANNE SOMMER

63 Darwin's bulbuls: South Asian cultures of bird fighting and Darwin's theory of sexual selection PROJIT BIHARI MUKHARJI

81 Of lice and men: Charles Darwin, Henry Denny and the evidence for the human races as varieties or species GREGORY RADICK AND MARK STEADMAN

97 'Unravelling Babel': Mary LeCron Foster on the origins of language JUDITH R. H. KAPLAN

115 Darwin's bawdy: the popular, gendered and radical reception of the Descent of Man in the US, 1871-1910 KIMBERLY A. HAMLIN

133 The evolution of Darwinian sexualities ERIKA LORRAINE MILAM

157 Charles Darwin, sexual selection and the evolution of other-regarding ethics PIERS J. HALE

179 Evolutionary antagonisms and the progress of three categories of traits NASSER ZAKARIYA

201 The late ascent of Darwin's Descent: exploring human evolution and women's role for a new China, $1927-1965$ LIJING JIANG

\section{B S H S}

THE BRITISH

SOCIETY FOR

THE HISTORY

OF SCIENCE

Published for The British Society for the History of Science

by Cambridge University Press

For further information about this journal please go to the journal website at: cambridge.org/bjt

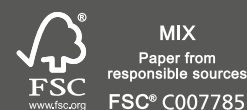

$\mathrm{FSC}^{\oplus} \mathrm{C007785}$
CAMBridge UNIVERSITY PRESS 